\title{
Sporadic hypercalcitoninemia: clinical and therapeutic consequences
}

\section{Scheuba, KKaserer ${ }^{1}$, A Moritz $^{2}$, R Drosten $^{3}$, H Vierhapper $^{4}$, C Bieglmayer $^{5}$, $O$ A Haas $^{2}$ and B Niederle}

\author{
Division of General Surgery, Section of Endocrine Surgery, Department of Surgery, Medical University of Vienna, Währinger Gürtel \\ 18-20, A-1090 Vienna, Austria \\ ${ }^{1}$ Department of Clinical Pathology, Medical University of Vienna, Wahringer Gürtel 18-20, A-1090 Vienna, Austria \\ ${ }^{2}$ Children's Cancer Research Institute, Kinderspitalgasse 6, A-1090 Vienna, Austria \\ ${ }^{3}$ Radiology Department, University of Utah, Salt Lake City, Utah, UT 84132, USA \\ ${ }^{4}$ Division of Endocrinology and Metabolism, Department of Internal Medicine III, Medical University of Vienna, Wahringer Gürtel \\ 18-20, A-1090 Vienna, Austria \\ ${ }^{5}$ Clinical Institute for Medical and Chemical Laboratory Diagnostics, Medical University of Vienna, Wahringer Gürtel 18-20, A-1090 \\ Vienna, Austria
}

(Correspondence should be addressed to C Scheuba; Email: christian.scheuba @ meduniwien.ac.at;

B Niederle; Email: bruno.niederle@meduniwien.ac.at)

\begin{abstract}
'Calcitonin screening' is not accepted as the standard of care in daily practice. The clinical and surgical consequences of 'calcitonin screening' in a series of patients with mildly elevated basal calcitonin and pentagastrin stimulated calcitonin levels are presented. 260 patients with elevated basal $(>10 \mathrm{pg} / \mathrm{ml})$ and stimulated calcitonin levels $(>100 \mathrm{pg} / \mathrm{ml})$ were enrolled in this prospective study. None of the patients was member of a known medullary thyroid carcinoma family. Thyroidectomy and bilateral central and lateral neck dissections were performed. Testing for the presence of germ-line mutations was performed in all patients. Histological and immunohistochemical findings were compared with basal and stimulated calcitonin levels. All patients were subsequently followed biochemically. C-cell hyperplasia (CCH) was found in $126(49 \%)$ and medullary thyroid cancer was found in $134(51 \%)$ patients. RET proto-oncogen mutations were documented in 22 (8\%) patients (medullary thyroid cancer:18, $\mathrm{CCH}: 4)$. In $56(46 \%)$ of 122 patients, sporadic $\mathrm{CCH}$ was classified neoplastic ('carcinoma in situ'). Of 97 (72\%; 10 with hereditary medullary thyroid cancer) had pT1 (International Union against Cancer recommendations 2002) and $33(25 \%)$ had pT2 or pT3 and 4 (3\%) pT4 tumors. Of $39(29.1 \%)$ had lymph node metastases. 106 (79.1\%; 15 (38.5\%) with lymph node metastases) patients were cured. Evaluation of basal and stimulated calcitonin levels enables the prediction of medullary thyroid cancer. All patients with basal calcitonin $>64 \mathrm{pg} / \mathrm{ml}$ and stimulated calcitonin $>560 \mathrm{pg} / \mathrm{ml}$ have medullary thyroid cancer. Medullary thyroid cancer was documented in $20 \%$ of patients with basal calcitonin $>10 \mathrm{pg} / \mathrm{ml}$ but $<64 \mathrm{pg} / \mathrm{ml}$ and stimulated calcitonin $>100 \mathrm{pg} / \mathrm{ml}$ but $<560 \mathrm{pg} / \mathrm{ml}$.

Endocrine-Related Cancer (2009) 16 243-253
\end{abstract}

\section{Introduction}

Serum calcitonin is the most sensitive biochemical marker for medullary thyroid carcinoma for both primary diagnosis and for follow-up.

Despite the ever increasing number of publications recommending routine calcitonin measurements in patients with thyroid nodules to diagnose medullary thyroid cancer in an early and therefore curable stage
(Pacini et al. 1994, Rieu et al. 1995, Niccoli et al. 1997, Vierhapper et al. 1997, 2005, Ozgen et al. 1999, Hahm et al. 2001, Elisei et al. 2004, Papi et al. 2006, Costante et al. 2007), 'calcitonin screening' is not recommended in daily practice (Hegedus 2004). Differences exist in the literature (Scheuba et al. 1999, Iacobone et al. 2002, Costante et al. 2007) regarding calcitonin cut-off levels, indication, time, and extent of surgery. 
This analysis aims to present the clinical and therapeutic implications of routinely performed 'calcitonin screening' in a large series of patients with 'sporadic' elevated basal and pentagastrin stimulated calcitonin levels.

\section{Patients and methods}

\section{Patients}

260 consecutive patients (167 males (67\%); 93 females (36\%): $\mathrm{f}: \mathrm{m}=1: 1.8$; Table 1 ) enrolled in this prospective 10 year study and were diagnosed by a calcitonin screening program (Vierhapper et al. 1997), demonstrating elevated basal $(>10 \mathrm{pg} / \mathrm{ml})$ and elevated stimulated ( $>100 \mathrm{pg} / \mathrm{ml}$ ) calcitonin levels (Barbot et al. 1994). If basal calcitonin levels were higher than $100 \mathrm{pg} / \mathrm{ml}$, the stimulated calcitonin levels had to be at least twice the basal calcitonin levels (Barbot et al. 1994).

Patients with various nodular thyroid diseases and elevated CT levels were selected for thyroid surgery in four different out-patient departments. No patient was a member of a known medullary thyroid cancer family, or had undergone surgery for medullary thyroid carcinoma.

Table 1 Demographics - medullary thyroid cancer and C-cell hyperplasia

\begin{tabular}{|c|c|c|c|c|c|c|}
\hline & \multicolumn{3}{|c|}{ C-cell hyperplasia (only) } & \multicolumn{3}{|c|}{ Medullary thyroid cancer } \\
\hline & Sporadic & Hereditary & $\Sigma$ & Sporadic & Hereditary & $\Sigma$ \\
\hline$N$ & $122(87 \%)$ & $4(13 \%)$ & 126 & $116(87 \%)$ & $18(13 \%)$ & $134(100 \%)$ \\
\hline Female & $14(12 \%)$ & $1(25 \%)$ & $15(12 \%)$ & 66 & 12 & $78(58 \%)$ \\
\hline Male & $108(89 \%)$ & $3(75 \%)$ & $111(88 \%)$ & 50 & 6 & $56(42 \%)$ \\
\hline \multicolumn{7}{|l|}{ Age } \\
\hline Median \pm S.D. & $(54.5 \pm 12.26)$ & $(60.5 \pm 9.74)$ & $(55 \pm 12.2)$ & $(59.5 \pm 12.7)$ & $(57 \pm 20.6)$ & $(59.3 \pm 13.9)$ \\
\hline Range & $(21-75)$ & $(48-69)$ & $(21-75)$ & $(27-83)$ & $(15-79)$ & $(15-83)$ \\
\hline Female & 14 & 1 & 15 & 66 & 12 & 78 \\
\hline Years + S.D. & $(45 \pm 13.3)$ & 55 & $(46 \pm 12.9)$ & $(59.9 \pm 14.2)$ & $(57 \pm 20.5)$ & $(59.3 \pm 15.2)$ \\
\hline Range & $(31-75)$ & 55 & $(31-75)$ & $(27-83)$ & $(24-79)$ & $(24-83)$ \\
\hline Male & 108 & 3 & 111 & 50 & 6 & 56 \\
\hline Years + S.D. & $(55.5 \pm 12.0)$ & $(66 \pm 11.4)$ & $(56 \pm 12.0)$ & $(59.3 \pm 10.6)$ & $(60.15 \pm 22.6)$ & $(59.3 \pm 12.3)$ \\
\hline Range & $(21-74)$ & $(48-69)$ & $(21-74)$ & $(32-81)$ & $(15-73)$ & $(15-81)$ \\
\hline \multicolumn{7}{|l|}{$\mathrm{pT}^{\star \star}$} \\
\hline $1 a$ & & & & 73 (63\%) & $8(44 \%)$ & $81(60 \%)$ \\
\hline $1 b$ & & & & 14 (12\%) & $2(11 \%)$ & $16(12 \%)$ \\
\hline 2 & & & & $15(13 \%)$ & $5(28 \%)$ & $20(15 \%)$ \\
\hline $3 a$ & & & & $2(2 \%)$ & 0 & $2(1 \%)$ \\
\hline $3 b$ & & & & $8(7 \%)$ & $3(17 \%)$ & $11(8 \%)$ \\
\hline $4 a$ & & & & $4(3 \%)$ & 0 & $4(3 \%)$ \\
\hline $4 b$ & & & & 0 & 0 & 0 \\
\hline Unifocal & & & & 93 (80\%) & $1(6 \%)$ & $99(74 \%)$ \\
\hline Multifocal & & & & $23(20 \%)$ & 17 (94\%) & $40(26 \%)$ \\
\hline \multicolumn{7}{|l|}{$\mathrm{pN}$} \\
\hline 0 & & & & 86 (74\%) & $9(50 \%)$ & 95 (71\%) \\
\hline 1 & & & & $30(26 \%)$ & $9(50 \%)$ & $39(29 \%)$ \\
\hline \multicolumn{7}{|l|}{$\mathrm{CCH}$} \\
\hline No & 0 & 0 & 0 & 52 & 6 & 58 \\
\hline Yes & 122 & 4 & 126 & 64 (55\%) & $12(61 \%)$ & 76 (56\%) \\
\hline Focal & 3 & 0 & 3 & 12 & 0 & 12 \\
\hline Diffuse & 25 & 0 & 25 & 11 & 1 & 12 \\
\hline Nodular & 38 & 1 & 39 & 9 & 5 & 14 \\
\hline Neoplastic & 56 & 3 & 59 & 32 & 6 & 38 \\
\hline Cured & $122(100 \%)$ & $4(100 \%)$ & $126(100 \%)$ & 95 (82\%) & $11(61 \%)$ & $106(79 \%)$ \\
\hline if NO & & & & 83 & 8 & 91 \\
\hline $\mathrm{N} 1$ & & & & 12 & 3 & 15 \\
\hline $\begin{array}{l}\text { Persisting } \\
\quad \text { disease (M) }\end{array}$ & & & & $21(18 \%)$ & 7 (39\%) & $28(21 \%)$ \\
\hline If NO & & & & 3 & 1 & 4 \\
\hline N1 & & & & 18 & 6 & 24 \\
\hline
\end{tabular}

T, tumor; N, lymph node metastasis; $\mathrm{CCH}$, C-cell hyperplasia; M, distant metastasis; N0, no lymph node metastases; N1, lymph node metastases; M, distant metastases. *UICC 2002/2003. 


\section{Biochemical analysis}

Calcitonin levels were determined either by an IRMA (IRMA-CIS-Biointernational, Gif-Sur-Yvette, France) or by an immunochemiluminometric assay (ICMANichols Diagnostics, San Juan Capistrano, CA, USA) in one laboratory (Bieglmayer et al. 2002).

In the first period of the study, the CIS assay was used and during the second period the Nichols assay was used. Method comparison studies (Bieglmayer et al. 2002) demonstrated the CIS and the Nichols assays (correlation coefficient: 0.91) to have the same results (and therefore the same cut-off levels).

\section{Surgery}

All patients underwent primary (total) thyroidectomy and microdissection of the central lymph node compartments along both recurrent nerves (central neck dissection; lymph node compartment C1 (Dralle 2002)).

A systematic microdissection of both lateral lymph node compartments (functional lateral neck dissection; compartments C2/C3 (Dralle 2002)) was added if medullary thyroid cancer was established by intraoperative frozen-section.

No transsternal mediastinal dissection (compartment C4 (Dralle 2002)) was performed during initial surgery.

\section{Molecular genetic analysis}

The presence of germ-line mutations was tested for all patients by screening exons $8,10,11,13,14,15$, and 16 of the RET proto-oncogene (Fink et al. 1996).

\section{Pathologic examinations}

All thyroid glands were submitted to pathology and inspected macroscopically. As recommended by Kaserer et al. (2002), the entire organ was sectioned in slices of $\sim 3-5 \mathrm{~mm}$ and frozen sections were performed on the macroscopically identified primary tumor. The entire remaining thyroid gland was serially blocked in paraffin. Sections of each block, as well as 3 sections of each submitted lymph node were stained with hematoxylin and eosin (H\&E). Immunohistochemistry was performed using the avidin-biotin-peroxidase technique. A section of each block was immunostained for calcitonin, using an available antibody (Chemicon, Temecula, CA, USA) in a dilution of 1:600.

C-cell hyperplasia $(\mathrm{CCH})$ was considered present when at least one area with $>50 \mathrm{C}$-cells per one low power field $(\times 100)$ was found in both thyroid lobes. The highest number of C-cells per low power field of each thyroid specimen was recorded. According to the growth pattern of C-cells, $\mathrm{CCH}$ was morphologically classified into focal, diffuse, or nodular (summarized as 'physiological CCH'; Rosai et al. 1992).

Focal $\mathrm{CCH}$ was defined by a segmental proliferation of C-cells within thyroid follicles. Diffuse $\mathrm{CCH}$ was diagnosed when C-cells formed an intrafollicular, circumferential collar around the more centrally located follicular epithelial cells. Nodular $\mathrm{CCH}$ was diagnosed when there was complete obliteration of the follicular lumen by hyperplastic C-cells (Kaserer et al. 2002).

'Neoplastic' $\mathrm{CCH}$ was diagnosed as an additional, separate form of $\mathrm{CCH}$, whenever intrafollicular C-cells with nuclear pleomorphism morphologically distinct from the follicular cells and therefore recognizable on $\mathrm{H} \& \mathrm{E}$-stained sections were seen.

Areas of C-cell proliferation with suspected early infiltration were regarded as medullary thyroid cancer. C-cell carcinoma was diagnosed, if a focal loss or reduplication of the basement membrane was demonstrated by immunohistochemistry (McDermott et al. 1995).

Tumors were staged in accordance with the International Union against Cancer recommendations (UICC) 2002/2003 (Wittekind et al. 2002; Wittekind et al. 2003).

\section{Postoperative follow-up}

All patients were followed clinically and biochemically. Basal and stimulated calcitonin levels were determined at 6 weeks, 6 months and then annually following surgery. Patients appeared to be cured when both the basal and the stimulated calcitonin levels remained below $10 \mathrm{pg} / \mathrm{ml} 12$ months following surgery. Persistently, high basal and/or stimulated calcitonin levels were called 'persisting' disease. Elevated basal and/or stimulated calcitonin levels 12 months after previous normalization was defined as 'recurrent' disease.

All patients gave informed consent to all diagnostic and therapeutic procedures.

\section{Statistical methods}

The SPSS program (Version 12.0.1; 2003 Chicago, IL, USA) was used for statistic analysis. Data is described as the mean \pm S.D. ( \pm S.D). Student's $t$ and $\chi^{2}$ calculations were applied for comparative analysis. $P$ values $\leq 0.05$ were considered to be significant.

\section{Results}

\section{Morphological results}

$134(51.5 \%)$ patients had medullary thyroid cancer and $126(48.5 \%)$ patients had CCH (Table 1). More males 
$(n=111)$ than females $(n=15)$ had $\mathrm{CCH}$ (female:male $=1: 7.4 ; \chi^{2}$ Test: $\left.P<0.001\right)$ while more females $(n=78)$ than males $(n=56)$ had medullary thyroid cancer (female:male $=1: 0.7 ; \chi^{2}$ Test: $P<0.001$ ).

\section{Medullary thyroid carcinoma}

According to the UICC 2002 (Wittekind et al. 2002; Wittekind et al. 2003), 81 (60\%) of 134 tumors were classified as pT1a (tumor diameter $\leq 10 \mathrm{~mm}$ ), 16 $(12 \%)$ as pT1b (11-20 mm), $20(15 \%)$ as pT2 $(21-40 \mathrm{~mm}), 2(2 \%)$ as pT3a $(>41 \mathrm{~mm}$ and intrathyroidal), $11(8 \%)$ as pT3b (tumors with minimal extension beyond the thyroid capsule) and $4(3 \%)$ as pT4a (tumor of any size extending beyond the thyroid capsule invading the s.c. soft tissues, larynx, trachea, esophagus, or the recurrent laryngeal nerve (Table 1). No tumor was classified as pT4b (tumor of any size invading the prevertebral fascia or invading the carotid artery or mediastinal vessels)

Mean tumor diameter measured $12.9 \pm 4.5$ (range: 0.5-90.0) $\mathrm{mm}$.

On average 71 (range 2-188) lymph nodes were dissected, in the medullary thyroid cancer patients. Of 39 patients (29\%) had lymph node metastases (Table 1). In those in whom lymph node metastases were found, a mean of 9.4 (range 1-48) lymph nodes were positive.

The frequency and the typing of concomitant $\mathrm{CCH}$ are shown in Table 1.

Concomitant $\mathrm{CCH}$ was demonstrated immunohistochemically in $76(56 \%)$ patients. $32(27.6 \%)$ patients with sporadic and $6(33.3 \%)$ with hereditary medullary thyroid cancer showed 'physiological $\mathrm{CCH}^{2}$ while $\mathrm{CCH}$ was classified as 'neoplastic' in 32 (27.5\%) sporadic and $6(33.3 \%)$ hereditary cases respectively.

The pathohistological reports described macroscopic 'near normal thyroid tissue' in addition to the foci of sporadic or hereditary medullary thyroid cancer in 40 (29.9\%). However, all patients showed mirconodules $(\leq 2 \mathrm{~mm})$ histologically. One or more hyperplastic macro-nodules $(>2 \mathrm{~mm})$ or diffuse enlargement was described in $74(55.3 \%)$ and $2(1.4 \%)$ glands respectively. Signs of Hashimoto's thyroiditis were found in 18 $(13.4 \%)$.

$21(18.1 \%)$ of the sporadic and 1 hereditary patient had an associated thyroid carcinoma derived from the follicular epithelium.

By definition, 106 (79\%) patients were clinically and biochemically cured by surgery (Table 1 ). Within the observation period of $4.5 \pm 3.06(0.9-11.7)$ years, 3 patients died from persistent medullary thyroid cancer 11, 18, and 79 months after surgery respectively.
No clinical or biochemical 'recurrent' disease was documented on the follow-up of patients considered to be cured initially.

\section{C-cell hyperplasia}

$66(54.1 \%)$ sporadic patients showed one of the various 'physiologic' and 56 (45.1\%) showed 'neoplastic' CCH types. All but 1 of the 4 patients with hereditary $\mathrm{CCH}$ showed the 'neoplastic' variant (Table 1).

In addition to the sporadic or hereditary $\mathrm{CCH}$ the pathohistological reports describe macroscopic near 'normal thyroid tissue' in $23(18.2 \%)$ patients (definitions see above). One or more hyperplastic macro-nodules were described in $81(64.3 \%)$ patients and diffuse enlargement of the gland in $7(5.6 \%)$ patients respectively. Hashimoto Thyroiditis was diagnosed in 15 (11.9\%).

$25(20.5 \%)$ sporadic and 2 hereditary patients had an associated thyroid carcinoma derived from the follicular epithelium.

All patients with $\mathrm{CCH}$ were biochemically cured.

\section{Molecular genetic results}

Table 2 summarizes the molecular genetic findings in 22 patients $(8.5 \%$; medullary thyroid cancer: 18 (13.4\%) of 134 patients; $\mathrm{CCH}: 4$ (3.2\%) of 126 patients) with various RET-proto-oncogen mutations and their genotype-phenotype correlation (Eng 1996).

In 9 patients with hereditary medullary thyroid cancer, a 'common mutation' in the extra-cellular domain of the RET-proto-oncogen of exons 10 or 11 was documented, while nine patients had mutations of exons $8,13,14$, or 15 ('rare mutations'). All patients with hereditary $\mathrm{CCH}$ had mutations of exon 13 , codon 791. No patient showed mutations of exon 16.

\section{Correlation of calcitonin levels, C-cell morphology and patients characteristics}

In accordance with the 'receiver operating characteristic curves' in Scheuba et al. (1999), the 260 patients were divided into patients with 'Mildly' elevated stimulated calcitonin levels (Group $1-\mathrm{CCH}$ or medullary thyroid cancer; Biochemical definition/ 'cut off' calcitonin levels: in normal renal function ( = creatinine $<1.5 \mathrm{mg} / \mathrm{ml}$ ); basal calcitonin $>10 \mathrm{pg} / \mathrm{ml}$ $\leq 64 \mathrm{pg} / \mathrm{ml}$ and stimulated calcitonin $>100 \mathrm{pg} / \mathrm{ml}$ $<560 \mathrm{pg} / \mathrm{ml}$ ) and into patients with 'Highly' elevated stimulated calcitonin levels (Group 2 - medullary thyroid cancer $100 \%$; Biochemical definition/cut off calcitonin levels: normal renal function; basal 
Table 2 Genotype-phenotype correlation in RET proto-oncogen carrier (index patients)

\begin{tabular}{|c|c|c|c|c|c|c|c|c|c|c|c|}
\hline \multirow[b]{3}{*}{ Exon } & \multirow[b]{3}{*}{ Codon } & & & \multicolumn{5}{|c|}{ Hereditary medullary thyroid cancer } & \multicolumn{2}{|c|}{$\begin{array}{l}\text { Hereditary C-cell } \\
\text { hyperplasia }\end{array}$} & \multirow[b]{3}{*}{$\Sigma$} \\
\hline & & \multicolumn{2}{|c|}{ AA exchange } & & & \multicolumn{3}{|c|}{ MEN2A } & & \multirow[b]{2}{*}{ FMTC } & \\
\hline & & & & & FMTC & 1 & 2 & 3 & & & \\
\hline 8 & 533 & $\mathrm{GGC}>\mathrm{TGC}$ & gly $>$ cys & 1 & 1 & & & & 0 & & 1 \\
\hline \multirow[t]{3}{*}{10} & 611 & TGC $>$ TGG & cys $>$ try & 1 & & & 1 & & 0 & & 1 \\
\hline & 611 & $\mathrm{TGC}>\mathrm{TAC}$ & cys $>$ arg & 1 & & & 1 & & 0 & & 1 \\
\hline & 620 & $\mathrm{TGC}>\mathrm{TAC}$ & cys $>$ arg & 1 & & & 1 & & 0 & & 1 \\
\hline \multirow[t]{2}{*}{11} & 634 & $\mathrm{TGC}>\mathrm{CGC}$ & cys $>$ arg & 4 & 1 & 2 & 1 & & 0 & & 4 \\
\hline & 634 & $\mathrm{TGC}>\mathrm{TAC}$ & cys $>$ tyr & 2 & 1 & 1 & & & 0 & & 2 \\
\hline \multirow[t]{2}{*}{13} & 790 & TTG > TTT & leu $>$ phe & 1 & 1 & & & & 0 & & 1 \\
\hline & 791 & TAT $>$ TTT & tyr $>$ phe & 1 & 1 & & & & 4 & 0 & 5 \\
\hline 14 & 804 & GTG $>$ ATG & val $>$ met & 4 & 3 & & & 1 & 0 & & 4 \\
\hline 15 & 891 & $\mathrm{TCG}>\mathrm{GCG}$ & ser $>$ ala & 2 & 1 & & 1 & & 0 & & 2 \\
\hline \multirow[t]{2}{*}{$\Sigma$} & & & & & 9 & 3 & 5 & 1 & & 4 & \\
\hline & & & & 18 & & & & & 4 & & 22 \\
\hline
\end{tabular}

FMTC, medullary thyroid cancer; MEN, multiple endocrine neoplasia; Pheo, pheochromocytoma; PHPT, primary hyperparathyroidism; tyr, tyrosine; phe, phenylalanine; cys, cysteine; trp, tryptophan; leu, leucine; val, valine; ser, serine; met, methionine; MEN2A-1, MTC+Pheo+PHPT; MEN2A-2, MTC+Pheo; MEN2A-3, MTC+PHPT.

calcitonin $>64 \mathrm{pg} / \mathrm{ml}$ or basal calcitonin $>10 \mathrm{pg} / \mathrm{ml}$ and (independent renal function) stimulated calcitonin $\geq 560 \mathrm{pg} / \mathrm{ml}$; Table 3 ).

\section{Group 1: 'mildly elevated' stimulated calcitonin levels}

\section{Group 1a-medullary thyroid cancer}

Medullary thyroid cancer measuring $0.7-7.0 \mathrm{~mm}$ was diagnosed by frozen section in 11 (35\%) patients. Frozen sections were negative in $20(65 \%)$ patients (diameter: 0.6-7.0 $\mathrm{mm}$ ) and thus only bilateral central but no lateral functional neck dissections were performed on these patients. All 31 tumors were classified as pT1a. In one (2.9\%) female, 4 of 73 lymph nodes showed metastatic involvement.

\section{Group $1 b-C$-cell hyperplasia}

'Physiological' $\mathrm{CCH}$ was documented in $67(53 \%)$ patients. 'Neoplastic' CCH was diagnosed in 59 (47\%) patients.

By definition, all patients of group 1a and $1 \mathrm{~b}$ were biochemically cured.

\section{Group 2: 'highly' elevated stimulated calcitonin levels}

Medullary thyroid cancer was biochemically predicted preoperatively in all 103 patients.

$50(48.5 \%)$ of 103 patients who were classified as pT1a, $38(36.9 \%)$ showed lymph node metastases at the time of diagnosis.

\section{Pentagastrin stimulated calcitonin levels, morphology, gender, and outcome}

Increasing stimulated calcitonin levels (steps of $200 \mathrm{pg} / \mathrm{ml}$ ) demonstrated a highly significant linear trend in the increase of patients with medullary thyroid cancer and a decrease of patients with $\mathrm{CCH}$ $(P<0.0001$; Table 4).

Overall, more females than males had medullary thyroid cancer $(P<0.01$; Table 4$)$. In the two subgroups with stimulated calcitonin levels between 100 and $200 \mathrm{pg} / \mathrm{ml}$ and $201-400 \mathrm{pg} / \mathrm{ml}$ medullary thyroid cancer was significantly more frequently documented in females than in males $(P<0.01$; Table 4$): 7$ of $18(39 \%)$ and 7 of 9 (78\%) females compared with 13 of $90(14 \%)$ and 5 of 36 (14\%) males showed medullary thyroid cancer $(P<0.01$; Table 4).

Patients with lymph node metastases and with persistent disease corresponding to different stimulated calcitonin subgroups are summarized in Table 4.

\section{Discussion}

This is the first single-center series of 260 patients with various nodular thyroid diseases and "sporadic hypercalcitoninemia' that applies the same diagnostic and therapeutic work-up, therefore allowing correlation of biochemical and morphological data and recommendations for therapy. Since the elevated basal and stimulated CT levels were known preoperatively, and therefore MTC was suspected, all patients were treated as if they had MTC. 
Table 3 Calcitonin 'cut off' levels to predict medullary thyroid cancer ${ }^{\mathrm{a}}$

\begin{tabular}{|c|c|c|c|c|c|c|c|c|c|}
\hline \multirow[b]{3}{*}{ PG-test } & \multirow{2}{*}{\multicolumn{3}{|c|}{$\frac{\text { Calcitonin (pg/ml; cut off levels) }}{\text { Basal and stimulated }}$}} & \multicolumn{4}{|c|}{ Histology } & & \\
\hline & & & & \multicolumn{2}{|c|}{$\mathrm{CCH}$} & \multicolumn{2}{|c|}{ MTC } & \multicolumn{2}{|c|}{$\Sigma$} \\
\hline & & & & $n$ & $\%$ & $n$ & $\%$ & $n$ & $\%$ \\
\hline Group 1 'Mildly’ elevated”* & $>10$ & $\leq 64$ & $<560$ & 126 & 80 & 31 & 20 & 157 & 60 \\
\hline \multirow[t]{3}{*}{ Group 2 'Highly' elevated** } & $>64$ & & Stimulated & 0 & 0 & 103 & 100 & 103 & 40 \\
\hline & $>10$ & $\leq 64$ & $\geq 560$ & & & & & & \\
\hline & & & & 126 & 48 & 134 & 52 & 260 & 100 \\
\hline
\end{tabular}

ROC curves see Scheuba et al. PG, Pentagastrin stimulation test; $\mathrm{CCH}$, C-cell hyperpasia; MTC, Medullary thyroid cancer. ${ }^{a}$ Normal renal function (creatinine $\leq 1.5 \mathrm{mg} / \mathrm{ml}$ ).

\section{Prevalence findings in the literature - arguments for and against calcitonin screening}

A series of original communications from Europe (Pacini et al. 1994, Papi et al. 2006, Costante et al. 2007) followed by editorial comments (Sheppard 1995, Deftos 2004, Elisei et al. 2004, Hodak \& Burman 2004) discuss the advantages and disadvantages of 'calcitonin screening' in patients with (Rieu et al. 1995, Ozgen et al. 1999, Hahm et al. 2001, Iacobone et al. 2002, Elisei et al. 2004, Vierhapper et al. 2005) and without (Karanikas et al. 2004) thyroid nodules, in an attempt to diagnose medullary thyroid cancer at an earlier and therefore potentially curable stage (Kebebew et al. 2000).

In terms of modern evidence-based medicine requirements, the available level of evidence for 'calcitonin screening' and its clinical and therapeutic consequences is limited. 'Calcitonin screening' is recommended routinely in patients with thyroid nodular disease in Europe (Sheppard 1995, Niccoli et al. 1997, Vierhapper et al. 1997, Lips et al. 2001) American authors (Deftos 2004, Hodak \& Burman 2004) argue against these recommendations. The main arguments against 'calcitonin screening' programs include the overall low frequency of medullary thyroid cancer, screening costs, and the difficulty acquiring pentagastrin for stimulation testing, which is necessary in patients with mild or moderate calcitonin elevation because there is no absolute threshold value for basal calcitonin levels that differentiates benign from malignant C-cell disease (Castro \& Gharib 2005).

\section{Routine calcitonin determinations ('calcitonin screening') or biopsy, cost effectiveness}

Routine calcitonin measurements show a higher sensitivity compared with fine needle aspiration cytology, especially in diagnosing small $(\leq 10 \mathrm{~mm})$ medullary thyroid cancer (Pacini et al. 1994, Niccoli et al. 1997, Ozgen et al. 1999, Bugalho et al. 2005, Papi et al. 2006). The costs of initial 'calcitonin screening' in patients with thyroid nodules independent of their size have to be balanced against that of multiple surgical procedures, and arguably worthwhile, but none-the-less frequently used, radiation and chemotherapy in patients with metastatic disease, as well as against the psychological effects of a 'chronic' disease (Dunn 1994, Horvit \& Gagel 1997, Vierhapper et al. 1997). The cost effectiveness of routine serum calitonin screening of patients undergoing evaluation

Table 4 Correlation of stimulated calcitonin levels, morphology, gender, lymph node involvement and persistence

\begin{tabular}{|c|c|c|c|c|c|c|c|c|}
\hline \multirow{2}{*}{$\begin{array}{l}\text { Stimulated } \\
\text { calcitonin } \\
(\mathrm{pg} / \mathrm{ml})\end{array}$} & \multirow[b]{2}{*}{$n$} & \multirow[b]{2}{*}{$\boldsymbol{n}(\mathrm{m} / \mathrm{f})$} & \multicolumn{2}{|c|}{$\mathrm{CCH}$} & \multicolumn{2}{|c|}{ MTC } & \multirow[b]{2}{*}{$\begin{array}{c}\text { LN pos } \\
n(\%)\end{array}$} & \multirow{2}{*}{$\begin{array}{c}\text { Follow-up } \\
\text { persistence } \\
n(\%)\end{array}$} \\
\hline & & & $n$ & $n$ & Male $n(\%)$ & $\begin{array}{c}\text { Female } n \\
(\%)\end{array}$ & & \\
\hline $100-200$ & 108 & $90 / 18$ & $88(81)$ & $20(19)$ & $13(14)^{*}$ & $7(39)^{\star}$ & $3(15)$ & $1(5)$ \\
\hline $201-400$ & 45 & $36 / 9$ & $33(73)$ & $12(27)$ & $5(14)^{\dagger}$ & $7(78)^{\dagger}$ & $2(17)$ & $1(8)$ \\
\hline $401-600$ & 15 & $8 / 7$ & $5(33)$ & $10(67)$ & $5(63)$ & $5(71)$ & 1 (10) & $1(10)$ \\
\hline $601-800$ & 6 & $5 / 1$ & 0 & $6(100)$ & $5(100)$ & $1(100)$ & $1(17)$ & 0 \\
\hline $801-$ & 86 & $28 / 58$ & 0 & $86(100)$ & $28(100)$ & $58(100)$ & $32(37)$ & $25(39)$ \\
\hline$\Sigma$ & 260 & $167 / 93$ & $126(48)$ & $134(52)$ & $56(34)$ & $78(84)$ & $39(29)$ & $28(21)$ \\
\hline
\end{tabular}

MTC, medullary thyroid cancer; $\mathrm{CCH}$, C-cell hyperplasia; LN, lymph node; pg, picogramme; ml, milliliter; $n$, number of patients; $\mathrm{m}$, male; $\mathrm{f}$, female. *Males versus females $P<0.01$ ( $\chi$ quadrat test). ${ }^{\dagger}$ Males versus females $P<0.01$ ( $\chi$ quadrat test). 
for thyroid nodules was shown by Shine (2002) and by Cheung et al. (2008).

Boi et al. (2007) recommend performing calcitonin measurements in wash-out fluids from fine needle aspiration to improve the diagnosis in primary and metastatic medullary thyroid carcinoma in the work-up thyroid nodules to prevent 'unnecessary' surgery. However, even this modification with fine needle aspiration evaluation may be inconclusive in 'calcitonin screened' patients, because medullary thyroid cancers measured from 0.7 to $7 \mathrm{~mm}$ in the group of patients with 'mildly elevated calcitonin levels'. Medullary thyroid cancer was diagnosed by frozen section in only $11(35 \%)$ of 31 patients.

\section{Normal calcitonin levels and medullary thyroid cancer}

Normal basal calcitonin values of $<10 \mathrm{pg} / \mathrm{ml}$ practically exclude medullary thyroid cancer (Pacini et al. 1994, Rieu et al. 1995, Niccoli et al. 1997, Kaserer et al. 1998, Ozgen et al. 1999, Hahm et al. 2001, Iacobone et al. 2002). Therefore, basal calcitonin levels of $\geq 10 \mathrm{pg} / \mathrm{ml}$ were used as the initial diagnostic tool to stratify for medullary thyroid cancer risk and this was defined as upper normal reference limit in most of the studies (Demers \& Spencer 2003). Elevation in the basal calcitonin levels alone is not evidence of medullary thyroid cancer (Costante et al. 2007). Stimulation tests (Demers \& Spencer 2003) are mandatory to confirm this suspicion. Patients with stimulated calcitonin levels of $30-100 \mathrm{pg} / \mathrm{ml}$ have a low risk $(<3 \%)$ for sporadic medullary thyroid cancer (Barbot et al. 1994, Iacobone et al. 2002). The risk for medullary thyroid cancer is greater than $50 \%$ in patients with stimulated calcitonin values $>100 \mathrm{pg} / \mathrm{ml}$ (Costante et al. 2007), quoting a minimal prevalence of medullary thyroid cancer of $0.26-1.37 \%$ (Pacini et al. 1994, Rieu et al. 1995, Niccoli et al. 1997, Vierhapper et al. 1997, Ozgen et al. 1999, Hahm et al. 2001, Papi et al. 2006, Costante et al. 2007). A higher stimulated calcitonin cut-off level (e.g., $200 \mathrm{pg} / \mathrm{ml}$ (Iacobone et al. 2002) would further increase the positive predictive value for medullary thyroid cancer, but more than a third of medullary thyroid cancers would escape diagnosis and treatment (Iacobone et al. 2002). Thus, the definition of $100 \mathrm{pg} / \mathrm{ml}$ as the therapeutic threshold reflects a clinical compromise, balancing over- and under-treatment in these patients. A strict interpretation of basal with stimulated calcitonin levels further increases the positive predictive value for the presence of medullary thyroid cancer (Scheuba et al. 1999).

\section{Elevated calcitonin levels and C-cell hyperplasia}

Elevated stimulated calcitonin levels $(>100 \mathrm{pg} / \mathrm{ml})$ were either associated with medullary thyroid cancer $(51.2 \%)$ or with various types of $\mathrm{CCH}(48.8 \%)$. There were no false-positive tests regarding these two entities when applying defined cut-off levels and strictly individualized combined interpretation of basal and stimulated calcitonin levels (Scheuba et al. 1999).

Age and sex both influence plasma calcitonin levels in normal human subjects (Deftos et al. 1980, Hahm et al. 2001). Calcitonin was generally higher in men than in women in each age group (Deftos et al. 1980, Hahm et al. 2001). Irrespective of age, the increase in calcitonin in response to stimulation was greater in men than in women (Deftos et al. 1980). Basal calcitonin levels and the response to stimulation waned with age in both sexes (Deftos et al. 1980).

Various types of $\mathrm{CCH}$ may be documented concomitantly to different benign and malignant thyroid disorders (Scheuba et al. 2000). No age- or gender-related differences in the occurrence of $\mathrm{CCH}$ in normal basal calcitonin and stimulated calcitonin levels were observed (Scheuba et al. 2000).

The term ' $\mathrm{CCH}$ ' refers to the (reactive) 'physiological' and 'neoplastic' variants. By definition, 67 (54.9\%) of the 122 patients with verified $\mathrm{CCH}$ morphologically fulfilled the criteria of 'physiological' and $59(48.3 \%)$ of 'neoplastic' CCH.

In 1 of 4 patients with RET proto-oncogen mutations, $\mathrm{CCH}$ was classified as 'physiologic', 3 as 'neoplastic'. Besides sporadic medullary thyroid cancer, 'physiological' and 'neoplastic' $\mathrm{CCH}$ was diagnosed in $32(27.6 \%)$ patients each, while histological examinations revealed 'physiological' $\mathrm{CCH}$ in six and 'neoplastic' $\mathrm{CCH}$ in another 6 of 18 patients with hereditary medullary thyroid cancer. In six patients no $\mathrm{CCH}$ was documented.

Different neoplastic potential is discussed for these two different pathologic conditions (Perry et al. 1996, LiVolsi 1997, Albores-Saavedra \& Krueger 2001). 'Neoplastic' CCH (so-called C-cell carcinoma in situ) is generally accepted as the precursor lesion of hereditary MTC, associated with germ-line mutations in the RET proto-oncogene. However, in our study, 'neoplastic' $\mathrm{CCH}$ was not documented in all patients with hereditary $\mathrm{CCH}$ or hereditary medullary thyroid cancer, but also in patients without genetic alterations.

The malignant potential of (reactive) 'secondary' or 'physiologic' $\mathrm{CCH}$ has not been fully demonstrated and its clinical relevance in the development of sporadic medullary thyroid cancer remains unclear (LiVolsi 1997, Verga et al. 2007). However, in one 
patient, a state of incipient medullary thyroid cancer emerging from nodular $\mathrm{CCH}$ was documented (Vierhapper et al. 1997). The hypothetical role of $\mathrm{CCH}$ as a risk factor for sporadic C-cell malignancy (Kaserer et al. 1998) is not supported by available evidence (LiVolsi 1997, Kaserer et al. 2002). Therefore, the clinical utility of histopathological documentation of the different variants of $\mathrm{CCH}$ particularly the 'neoplastic' variant to indicate genetic medullary thyroid cancer risk, is small as up to $50 \%$ of patients with sporadic medullary thyroid cancer or with sporadic CCH may have by definition (LiVolsi 1997) the 'neoplastic' $\mathrm{CCH}$.

\section{Elevated calcitonin levels and medullary thyroid cancer}

In this study, various types of $\mathrm{CCH}$ were more common in males than in females including patients with bCT levels $>10 \mathrm{pg} / \mathrm{ml}$ and $\mathrm{sCT}$ levels $>100 \mathrm{pg} / \mathrm{ml}$. The distinction of 'neoplastic $\mathrm{CCH}^{\prime}$ from microinvasive MTC may be very difficult in individual cases. Preoperatively, they cannot be discriminated biochemically (Scheuba et al. 1999, 2007). Morphologically 'neoplastic' CCH is characterized by groups of intrafollicular atypical CC with partial or complete obliteration of the follicular spaces (LiVolsi 1997). There is a progressive increase of the proliferation index accompanied by an increase of molecular alterations and monoclonality, leading to invasive MTC (Matias-Guiu et al. 1995). The presence of fibrosis around tumor cell nests and demonstration of defects in the follicular basement membrane by immunohistochemistry or electron microscopy may be helpful to definitively discriminate both entities (McDermott et al. 1995).

Medullary thyroid cancer was documented in 134 $(51.2 \%)$ of 260 patients. $103(76.9 \%)$ medullary thyroid tumors could be predicted biochemically during preoperative evaluation.

Without routine calcitonin measurements, medullary thyroid cancer will be identified as a palpable thyroid nodule reflecting a more advanced disease. The presence of lymph node and distant metastases at first diagnosis significantly worsens the prognosis (Kebebew et al. 2000, Scollo et al. 2003). Metastases to lymph nodes in the neck appear early. 39 (29.1\%) of 134 patients had lymph node metastases. Their frequency is roughly proportional to the size of the primary tumor. Hence, $10(12.3 \%)$ of 81 pT1 tumors had lymph node metastases at initial diagnosis. Although, patients with basal calcitonin $<22 \mathrm{pg} / \mathrm{ml}$ were all node negative (Scheuba et al. 1999), neither medullary thyroid cancer nor lymph node metastases could be predicted biochemically (Scheuba et al. 1999). Therefore, thyroidectomy and bilateral central neck dissection should be performed as the minimal initial treatment in patients selected for surgery by 'calcitonin screening'.

By definition, 106 (79\%) patients were clinically and biochemically cured by surgery. $15(38.5 \%)$ of 39 patients with lymph node metastases showed undetectable basal and stimulated calcitonin levels.

\section{Clinical and therapeutic consequences and recommendations}

Surprisingly, a better knowledge of the unique biochemical, molecular, genetic, and clinical features of medullary thyroid cancer neither lead to earlier diagnosis and treatment nor to improvement of survival in the USA (Kebebew et al. 2005). A high proportion of patients still receive less than optimal initial surgical treatment (Kebebew et al. 2005), especially when medullary thyroid cancer is small and therefore clinically unexpected.

'Calcitonin screening' in patients with solitary and multiple thyroid nodules improves the early detection of (clinically unexpected) medullary thyroid cancer. This may be useful in assessing for tumor spread preoperatively and may help in evaluation, allowing for a stage adapted, and therefore potentially curable, surgical procedure.

Medullary thyroid cancer can be predicted with $100 \%$ certainty in patients with 'highly' elevated stimulated calcitonin levels. Therefore, thyroidectomy with bilateral central $(\mathrm{C} 1)$ and bilateral (functional) lateral neck dissection $(\mathrm{C} 1-\mathrm{C} 3)$ is recommended as lymph node positive and lymph node negative patients cannot be differentiated biochemically. Bilateral, central, and lateral lymph nodes may be affected independent of the size, number, and location of the tumor and micrometastases may not be detectable by ultrasound. Involvement of mediastinal lymph nodes (C4) may be present. Transsternal mediastinal dissection may be performed in patients with a positive postoperative pentagastrin test during a second operation following the exclusion of distant metastases.

Differences exist in the proposals that address, cut-off levels, time, and extent of surgery in patients with 'mildly' elevated basal and stimulated calcitonin levels (Scheuba et al. 1999, Iacobone et al. 2002). Currently, biochemical differentiation between patients with 'C-cell hyperplasia only' and those with medullary thyroid microcarcinoma cannot be made preoperatively. 
Medullary thyroid cancer may sometimes not be diagnosed by frozen section in patients with 'mildly' elevated stimulated calcitonin levels, and therefore thyroidectomy and bilateral central neck dissection (C1) is the treatment of choice. Medullary thyroid carcinoma exists in only $20 \%$ in this 'gray zone' where $\mathrm{CCH}$ and medullary thyroid cancer overlap.

In contradistinction with Iacobone (Iacobone et al. 2002) who proposed C1-dissection only in patients with stimulated calcitonin levels $>200 \mathrm{pg} / \mathrm{ml}$, a central neck dissection is recommended in all patients with stimulated calcitonin levels $>100 \mathrm{pg} / \mathrm{ml}$ because lymph node metastases were documented in $3(15 \%)$ of 20 patients with stimulated calcitonin levels between 100 and $200 \mathrm{pg} / \mathrm{ml}$. A bilateral lateral neck dissection ( $\mathrm{C} 1-\mathrm{C} 3)$ may be performed 'on demand' after thyroidectomy and negative or positive $\mathrm{C} 1$ dissection, if postoperative basal calcitonin and/or stimulated calcitonin levels are measurable, indicating lymph node metastases outside the central neck.

\section{Conclusions}

During work-up of thyroid nodules routinely, the evaluation of basal and stimulated calcitonin levels additionally performed in patients with elevated basal hormone levels ('calcitonin screening') enables the prediction of medullary thyroid cancer. By definition, all patients $(100 \%)$ with 'highly elevated' calcitonin levels (basal calcitonin $>64 \mathrm{pg} / \mathrm{ml}$; stimulated calcitonin $>560 \mathrm{pg} / \mathrm{ml}$ ) suffer from medullary thyroid cancer. Therefore, 'adequate' curative primary surgery can be offered to these patients. Medullary thyroid cancer was documented in at least $20 \%$ of patients with 'mildly elevated' calcitonin levels (basal calcitonin $>10 \mathrm{pg} / \mathrm{ml}$ but $<64 \mathrm{pg} / \mathrm{ml}$ and stimulated calcitonin $>100 \mathrm{pg} / \mathrm{ml}$ but $<560 \mathrm{pg} / \mathrm{ml}$ ). In this select group, females are significantly more commonly affected by medullary thyroid cancer than males are. Therefore, a more 'liberal indication' for surgery is recommended in females with stimulated calcitonin levels up to $400 \mathrm{pg} / \mathrm{ml}$.

\section{Declaration of interest}

I declare that there is no conflict of interest that could be perceived as prejudicing the impartiality of the research reported.

\section{Funding}

This research did not receive any specific grant from any funding agency in the public, commercial or not-for-profit sector.

\section{References}

Albores-Saavedra JA \& Krueger JE 2001 C-cell hyperplasia and medullary thyroid microcarcinoma. Endocrine Pathology 12 365-377.

Barbot N, Calmettes C, Schuffenecker I, Saint-Andre JP, Franc B, Rohmer V, Jallet P \& Bigorgne JC 1994 Pentagastrin stimulation test and early diagnosis of medullary thyroid carcinoma using an immunoradiometric assay of calcitonin: comparison with genetic screening in hereditary medullary thyroid carcinoma. Journal of Clinical Endocrinology and Metabolism 78 114-120.

Bieglmayer C, Scheuba C, Niederle B, Flores J \& Vierhapper H 2002 Screening for medullary thyroid carcinoma: experience with different immunoassays for human calcitonin. Wiener Klinische Wochenschrift 114 267-273.

Boi F, Maurelli I, Pinna G, Atzeni F, Piga M, Lai ML \& Mariotti S 2007 Calcitonin measurement in wash-out fluid from fine needle aspiration of neck masses in patients with primary and metastatic medullary thyroid carcinoma. Journal of Clinical Endocrinology and Metabolism 92 2115-2118.

Bugalho MJ, Santos JR \& Sobrinho L 2005 Preoperative diagnosis of medullary thyroid carcinoma: fine needle aspiration cytology as compared with serum calcitonin measurement. Journal of Surgical Oncology 91 56-60.

Castro MR \& Gharib H 2005 Continuing controversies in the management of thyroid nodules. Annals of Internal Medicine 142 926-931.

Cheung K, Roman SA, Wang TS, Walker HD \& Sosa JA 2008 Calcitonin measurement in the evaluation of thyroid nodules in the United States: a cost effectiveness and decision analysis. Journal of Clinical Endocrinology and Metabolism 93 2173-2180.

Costante G, Meringolo D, Durante C, Bianchi D, Nocera M, Tumino S, Crocetti U, Attard M, Maranghi M, Torlontano M et al. 2007 Predictive value of serum calcitonin levels for preoperative diagnosis of medullary thyroid carcinoma in a cohort of 5817 consecutive patients with thyroid nodules. Journal of Clinical Endocrinology and Metabolism 92 450-455.

Deftos LJ 2004 Should serum calcitonin be routinely measured in patients with thyroid nodules - will the law answer before endocrinologists do? Journal of Clinical Endocrinology and Metabolism 89 4768-4769 (author reply 4769-4770).

Deftos LJ, Bone HG III \& Parthemore JG 1980 Immunohistological studies of medullary thyroid carcinoma and $\mathrm{C}$ cell hyperplasia. Journal of Clinical Endocrinology and Metabolism 51 857-862.

Demers L \& Spencer C 2003 Laboratory support for diagnosis and monitoring of thyroid disease. National Academy of Clinical Biochemistry, Washington DC, www.nacb.org/lmpg/thyroid.

Dralle H 2002 Lymph node dissection and medullary thyroid carcinoma. British Journal of Surgery 89 1073-1075. 
Dunn JT 1994 When is a thyroid nodule a sporadic medullary carcinoma? Journal of Clinical Endocrinology and Metabolism 78 824-825.

Elisei R, Bottici V, Luchetti F, Di Coscio G, Romei C, Grasso L, Miccoli P, Iacconi P, Basolo F, Pinchera A et al. 2004 Impact of routine measurement of serum calcitonin on the diagnosis and outcome of medullary thyroid cancer: experience in 10864 patients with nodular thyroid disorders. Journal of Clinical Endocrinology and Metabolism 89 163-168.

Eng C 1996 Seminars in medicine of the Beth Israel Hospital, Boston. The RET proto-oncogene in multiple endocrine neoplasia type 2 and Hirschsprung's disease. New England Journal of Medicine 335 943-951.

Fink M, Weinhäusel A, Niederle B \& Haas OA 1996 Distinction between sporadic and hereditary medullary thyroid carcinoma (MTC) by mutation analysis of the RET proto-oncogene. 'Study Group Multiple Endocrine Neoplasia Austria (SMENA)'. International Journal of Cancer 69 312-316.

Hahm JR, Lee MS, Min YK, Lee MK, Kim KW, Nam SJ, Yang JH \& Chung JH 2001 Routine measurement of serum calcitonin is useful for early detection of medullary thyroid carcinoma in patients with nodular thyroid diseases. Thyroid 11 73-80.

Hegedus L 2004 Clinical practice. The thyroid nodule. New England Journal of Medicine 351 1764-1771.

Hodak SP \& Burman KD 2004 The calcitonin conundrum-is it time for routine measurement of serum calcitonin in patients with thyroid nodules? Journal of Clinical Endocrinology and Metabolism 89 511-514.

Horvit PK \& Gagel RF 1997 The goitrous patient with an elevated serum calcitonin - what to do? Journal of Clinical Endocrinology and Metabolism 82 335-337.

Iacobone M, Niccoli-Sire P, Sebag F, De Micco C \& Henry JF 2002 Can sporadic medullary thyroid carcinoma be biochemically predicted? Prospective analysis of 66 operated patients with elevated serum calcitonin levels World Journal of Surgery 268.

Karanikas G, Moameni A, Poetzi C, Zettinig G, Kaserer K, Bieglmayer C, Niederle B, Dudczak R \& Pirich C 2004 Frequency and relevance of elevated calcitonin levels in patients with neoplastic and nonneoplastic thyroid disease and in healthy subjects. Journal of Clinical Endocrinology and Metabolism 89 515-519.

Kaserer K, Scheuba C, Neuhold N, Weinhäusel A, Vierhapper H, Haas OA \& Niederle B 1998 C-cell hyperplasia and medullary thyroid carcinoma in patients routinely screened for serum calcitonin. American Journal of Surgical Pathology 22 722-728.

Kaserer K, Scheuba C, Neuhold N, Weinhäusel A, Vierhapper H \& Niederle B 2002 Recommendations for reporting $\mathrm{C}$ cell pathology of the thyroid. Wiener Klinische Wochenschrift 114 274-278.

Kebebew E, Ituarte PH, Siperstein AE, Duh QY \& Clark OH 2000 Medullary thyroid carcinoma: clinical characteristics, treatment, prognostic factors, and a comparison of staging systems. Cancer 88 1139-1148.
Kebebew E, Greenspan FS, Clark OH, Woeber KA \& Grunwell J 2005 Extent of disease and practice patterns for medullary thyroid cancer. Journal of the American College of Surgeons 200 890-896.

Lips CJ, Hoppener JW \& Thijssen JH 2001 Medullary thyroid carcinoma: role of genetic testing and calcitonin measurement. Annals of Clinical Biochemistry 38 168-179.

LiVolsi VA 1997 C cell hyperplasia/neoplasia (editorial; comment). Journal of Clinical Endocrinology and Metabolism 82 39-41.

Matias-Guiu X, Peiro G, Esquius J, Oliva E, Cabezas R, Colomer A \& Prat J 1995 Proliferative activity in C-cell hyperplasia and medullary thyroid carcinoma. Evaluation by PCNA immunohistochemistry and AgNORs staining. Pathology, Research and Practice 191 42-47.

McDermott MB, Swanson PE \& Wick MR 1995 Immunostains for collagen type IV discriminate between C-cell hyperplasia and microscopic medullary carcinoma in multiple endocrine neoplasia, type 2a. Human Pathology 26 1308-1312.

Niccoli P, Wion-Barbot N, Caron P, Henry JF, de Micco C, Saint Andre JP, Bigorgne JC, Modigliani E \& ConteDevolx B 1997 Interest of routine measurement of serum calcitonin: study in a large series of thyroidectomized patients. The French Medullary Study Group.

Journal of Clinical Endocrinology and Metabolism 82 338-341.

Ozgen AG, Hamulu F, Bayraktar F, Yilmaz C, Tuzun M, Yetkin E, Tuncyurek M \& Kabalak T 1999 Evaluation of routine basal serum calcitonin measurement for early diagnosis of medullary thyroid carcinoma in seven hundred seventy-three patients with nodular goiter. Thyroid 9 579-582.

Pacini F, Fontanelli M, Fugazzola L, Elisei R, Romei C, Di Coscio G, Miccoli P \& Pinchera A 1994 Routine measurement of serum calcitonin in nodular thyroid diseases allows the preoperative diagnosis of unsuspected sporadic medullary thyroid carcinoma (see comments). Journal of Clinical Endocrinology and Metabolism 78 826-829.

Papi G, Corsello SM, Cioni K, Pizzini AM, Corrado S, Carapezzi C, Fadda G, Baldini A, Carani C, Pontecorvi A et al. 2006 Value of routine measurement of serum calcitonin concentrations in patients with nodular thyroid disease: a multicenter study. Journal of Endocrinological Investigation 29 427-437.

Perry A, Molberg K \& Albores-Saavedra J 1996 Physiologic versus neoplastic C-cell hyperplasia of the thyroid: separation of distinct histologic and biologic entities. Cancer 77 750-756.

Rieu M, Lame MC, Richard A, Lissak B, Sambort B, Vuong-Ngoc P, Berrod JL \& Fombeur JP 1995 Prevalence of sporadic medullary thyroid carcinoma: the importance of routine measurement of serum calcitonin in the diagnostic evaluation of thyroid nodules (see comments). Clinical Endocrinology 42 453-460. 
Rosai J, Carcangiu ML \& DeLellis RA 1992 Atlas of Tumor Pathology: Tumors of the Thyroid Gland. Washington, DC: Armed Forces Institute of Pathology.

Scheuba C, Kaserer K, Weinhäusel A, Pandev R, Kaider A, Passler C, Prager G, Vierhapper H, Haas OA \& Niederle B 1999 Is medullary thyroid cancer predictable? A prospective study of 86 patients with abnormal pentagastrin tests (in process citation) Surgery 126 1089-1095 (discussion 1096).

Scheuba C, Kaserer K, Kotzmann H, Bieglmayer C, Niederle B \& Vierhapper H 2000 Prevalence of C-cell hyperplasia in patients with normal basal and pentagastrin-stimulated calcitonin. Thyroid 10 413-416.

Scheuba C, Bieglmayer C, Asari R, Kaczirek K, Izay B, Kaserer K \& Niederle B 2007 The value of intraoperative pentagastrin testing in medullary thyroid cancer. Surgery 141 166-171 (discussion 171-162).

Scollo C, Baudin E, Travagli JP, Caillou B, Bellon N, Leboulleux S \& Schlumberger M 2003 Rationale for central and bilateral lymph node dissection in sporadic and hereditary medullary thyroid cancer. Journal of Clinical Endocrinology and Metabolism 88 2070-2075.

Sheppard MC 1995 Should serum calcitonin be measured routinely in all patients with nodular thyroid disease? Clinical Endocrinology 42 451-452.
Shine B 2002 Routine calcitonin measurement in management of thyroid nodules: a decision analysis approach. In Endorine Abstracts. Ed ECoE 2007: BioScientifica Ltd.

Verga U, Ferrero S, Vicentini L, Brambilla T, Cirello V, Muzza M, Beck-Peccoz P \& Fugazzola L 2007

Histopathological and molecular studies in patients with goiter and hypercalcitoninemia: reactive or neoplastic C-cell hyperplasia? Endocrine-Related Cancer 14 393-403.

Vierhapper H, Raber W, Bieglmayer C, Kaserer K, Weinhäusl A \& Niederle B 1997 Routine measurement of plasma calcitonin in nodular thyroid diseases. Journal of Clinical Endocrinology and Metabolism 82 1589-1593.

Vierhapper H, Niederle B, Bieglmayer C, Kaserer K \& Baumgartner-Parzer S 2005 Early diagnosis and curative therapy of medullary thyroid carcinoma by routine measurement of serum calcitonin in patients with thyroid disorders. Thyroid 15 1267-1272.

Wittekind C, Compton CC, Greene FL \& Sobin LH 2002 TNM residual tumor classification revisited. Cancer 94 2511-2516.

Wittekind C, Greene FL, Hutter RVP, Sobin LH, Henson DC (eds) 2003 TNM Supplement: a commentary on uniform use $\left(3^{\text {rd }}\right.$ ed) Hoboken, UK: Wiley. 